\title{
Micro Waqf Bank : Combination of Microfinance and Community Development in Islamic Finance
}

\author{
Listya Cahyaningrat ${ }^{1}$, Abdul Mongid ${ }^{2}$ \\ Program Studi Magister Manajemen-Universitas Hayam Wuruk Perbanas \\ \{2017610867@students.perbanas.ac.id\}
}

\begin{abstract}
This study aims to unveil the business processes, the business characteristics, and the benefits of the empowerment programs by Islamic Microfinance Institutions with the model Micro Waqf Bank located in Jombang Regency, East Java Province. The method used in this study is in-depth interviews, observations, and documentation conducted at Bank Wakaf Mikro Tebuireng Mitra Sejahtera, Bank Wakaf Mikro Denanyar Sumber Barokah, and Bank Wakaf Mikro Bahrul Ulum Barokah Sejahtera. These business entities are basically sharia microfinance institutions and incorporated as cooperative with the micro waqf as a marketing identity. This research compares and analysis the data from interviews with documentation and observations in the field and found interesting findings. Results show that although the business processes and characteristics of the business have in common with other cooperative lenders, the results of economic empowerment perceived by customers are strongly unique. Recipients of financing strongly benefited from the economic empowerment. These institutions are also benefited the surrounding community. The existence of these lending institutions under the pesantren improve the economic welfare of the surrounding community.
\end{abstract}

Keywords : Micro Waqf Bank, Business Process, Business Characteristics, Empowerment

\section{Introduction}

Economic empowerment is one of the keys to improving the welfare of the community, especially the Micro, Small, and Medium Enterprises sectors. There have been many government economic empowerment programs, either through various ministries, business service bodies and state-owned enterprises, or the private sector. One of the obstacles in the empowerment program carried out by several agencies is the incidental programs. When the period of the program has been through, the empowerment program will also end. Nevertheless, in some processes, many things have not been done during the empowerment process. For this reason, a sustainable concept of economic empowerment is needed and is not limited to incidental programs.

Micro Waqf Bank is one of the program models that involve pesantren in community economic empowerment. This Institution has a legal entity in cooperatives, while the operating permit is obtained from the Financial Services Authority of the Republic of Indonesia. Member of This Institution is the administrator of the pesantren and the teachers who teach schools in the pesantren. Micro Waqf Bank was established to solve economic problems in the community, especially those around the pesantren environment, by providing light business capital financing in terms of returns. 
Moreover, it aims to educate students in pesantren and their postgraduate to manage shariabased microfinance institutions. That way, the Micro Waqf Bank can run sustainable development and increase potential economic community around the pesantren. Even though this Institution is independent, it operationally still ties with some rules made by the donors. One of the rules that must apply is that this Institution can channel financing to the public without collateral. The system used is a joint responsibility which is added with a mentoring program weekly in the form of human resource development from both religious and business aspects.

One of this Institution's other characteristics is that the distribution of funds every financing time is limited to a maximum of IDR 3,000,000 per person. With the term, the due option is 20 weeks, 40 weeks, or 50 weeks. Other limitations This Institution is not allowed to collect funds from the public. So that the distribution of funds only comes from funds provided by donors to cooperatives.

Because the Micro Waqf Bank is a new model in Islamic Microfinance Institutions, there is no research that discusses its business processes. The process in question is starting from customer recruitment to the financing and coaching process. For this reason, this study takes one of these sections in its discussion.

\section{Theoretical Framework and Hypotheses}

The development of Islamic Microfinance Institutions in Indonesia has experienced a significant increase over the last ten years in line with the rapid growth Sharia banking. Microfinance Institutions plays a vital role in moving the wheels of the economy by working on the lowest segment of the economy that banks cannot accommodate in general. LKMS (stands for Lembaga Keuangan Mikro Shariah, translation : Sharia Micro Finance Institution) is a financial institution whose activities are to collect and distribute public funds that are profit or Islamic financial institutions informal non-banking. Called casual because this Institution was founded by the society, in contrast to banking financial institutions and other financial institutions. One of the Islamic microfinance institutions that are currently developing is the Micro Waqf Bank (BWM).

\section{Islamic Economics in Pesantren}

Pesantren is the oldest Islamic Educational Institution in Indonesia. Besides, history noted, pesantren is a bastion of the people's defense and the center of the spread of Islam in Indonesia. Islamization in Java was one of the successes of the ulama at that time. Even, Pesantren refers to as a subculture that has different characteristics from Javanese culture overall. Educated prospective religious leaders (Kyai) initially made efforts to grow the competency to reason and change the orientation of education pesantren (Kyai). From the start of the 20th century, general lessons began to be taught (Mastuhu, 1994).

Since 1945, Pesantren starts implementing the classical education system or madrasa and start teaching science generally. Some pesantren have also opened special pesantren for women (Eka, 2007). This change in the education system is the response of the founders of the pesantren to socio-political changes due to Dutch politics. This change also makes pesantren have two general types: traditional pesantren and modern pesantren.

The phenomenon also happens with the teaching of Islamic Economics in Islamic boarding schools (Pesantren). Islamic Economics with all branches and products are part of the Islamic sciences, not part of science conventional economics, although it is very likely and open that economists of conventional study and become experts in Islamic economics. The Epistemology 
of Islamic economics is built from revelation. Conventional economics originating and nonreligious epistemology (Azizy, 2004).

\section{Sharia Microfinance Institutions}

Sharia Microfinance Institutions, or MFI, are specifically established to provide business development services and community empowerment through loans or financing in micro-scale businesses to members and the public, managing deposits as consulting services business development that is not solely for profit. (UU No.1 Tahun 2013, About Microfinance Institutions). The purpose of establishing a Microfinance Institution is that the general public must seek gain so that the appropriate legal entity with these characteristics in Indonesia is cooperative.

Yunus (2010) defines the profit-nonprofit business as "social business." This is a new form of business in organizational structure, which is not the same as business profit maximization and not charity. The managerial mindset must still be just like in business. This social business thinks and works differently from running a charity; however, this is also different from maximizing profit. Social businesses are also expected to refund their total costs up to them can be independent. The owner should never intend to make a profit for themselves (no dividends), but they are entitled to their money back if they want it. Instead of being passed on to investors, the surplus generated by social businesses is reinvested. Thus, in the end, it can be forwarded to the target group of beneficiaries in the form of a higher price, lower cost, better service, or greater accessibility (M Yunus, 2010).

The role of MFI is no less critical, apart from financial support in business development managed by women is as a learning center. As covered in the sense of MFI in UU No. 1 of 2013 concerning MFI, one of the activities of MFI is the provision of business development consulting services. Which activity is should not be operationally commercialized? This function is often left out and only as a supporting role. Even though by assisting, both in business finance administration and socializing an understanding of the economy Islam, the purpose of the existence of microfinance will not deviate.

\section{Community development}

The term empowerment to society is individuals who combine with other individuals to build the community's culture. Empowering the community is an effort to strengthen elements of empowerment to increase the dignity of each layer of society in a state of inadequacy. It works by relying on their strength to get out of poverty and underdevelopment or the process of enabling and empowering culture. The concept of empowerment includes empowerment community related to the images: self-help, participation, network (networking), and equity (equity).

So, in the process of community empowerment, the main interesting points are: how the process takes place to strengthen the potential possessed by the community. For that reason, the DOUM principle applies (DOUM stands for Dari, Oleh, Untuk Masyarakat; translation: from, by, and for the community). In this process, society is the subject in every cycle or process. The community empowerment concept can be applied with 2 (two) main approaches: (1) community participation and (2) Community organizing.

Participation can be defined as the mental and emotional involvement of people in situations groups that encourage them to contribute to group goals and are equally responsible for it. Therefore, participation includes contact with other parties; respond to information; decision- 
making; implementation operational; receive, maintain, develop, and assess development outcomes.

In practice, there are groupings in the participation process: political participation, namely: the form of representation in democracy, social participation, namely community involvement in development process and citizen participation, namely direct decision-making in public policy. While the form of community participation can be in two types: the principles are different, namely: first, participation in joint activities in development special one. Second, participation as individuals outside of joint activities in the community development. These two types of participation have a distinctive characteristic known as ideas, an initiative that on the one hand comes from below (bottom-up), and the other party that comes from the top (topdown). Participation from below is likely more voluntary than coercion, whereas local participation from above often involves some pressure. In addition to this, there is participation driven through certain rewards.

Community organizing is planning, organizing, or project development of various activities and community programs or projects. The main goal is to increase the standard of living or social welfare. As an activity collectively, community organizing involves several factors such as companions, local communities, donor agencies, and related agencies that work together starting from design, implementation to the evaluation of the program. The perspective of community organizing is divided into two parts: professional and radical approaches. The professional approach points to improving independence and improving the service delivery system within social relations. This approach can be labeled as traditional, neutral, and technical. While the radical approach is more focused on efforts to empower groups weakly, look for the causes of their weakness, and analyze the sources his oppression. The radical approach is labeled as a transformational approach.

In organizing and empowering the community, three models can be used to understand the concept. (1) Local community development model, providing changes in society, can be carried out optimally if it involves broad active participation across all spectrums of local-level communities, both in the change determination stage. (2) Social planning model emphasizes the process of technical problem solving to substantive social problems, such as poverty, unemployment, juvenile delinquency, ignorance, poor public health, mental health, slums, drug abuse, prostitution, and other problems. (3) Model of Social Action. How important the handling in an organized, directed, and systematically against disadvantaged groups.

Both of these approaches are empowerment processes that apply the DOUM principle above. This concept is part of the community development process, a social movement to realize an idea. In general, the empowerment model aims to reduce poverty, recover the impact of the crisis, provide facilities and infrastructure according to community needs, develop and strengthen the capacity of individuals and community organizations, local economic development, institutional capacity development, and local regulations.

The targets are areas with high poverty levels, villages, underdeveloped sub-districts/ regencies, and communities with facilities and infrastructure lacking-beneficiaries of households or groups of poor people. In the implementation, using a group formation strategy that involves a facilitator as a companion, the existence of consultants at the village, sub-district and district levels, the existence of forums discussion forums at every level, in collaboration with local governments at all levels, involving groups business, funding comes from many parties (Government, donor agencies, and from community) (Rukminto, 2008). 


\section{Women empowerment}

Etymologically, empowerment (permberdayaan) comes from the bare word "daya" which means strength or power ability. Through this definition, empowerment is interpreted as a process of obtaining power, strength, or ability, and or the granting of power, strength, or the ability of the party who has the power to the party that is less or not yet powerless (Sulistiyani, 2004). Meanwhile, according to Prijono and Pranarka (1996), empowerment is a process for the community to become empowered, encourage or motivate individuals to have the ability or empowerment to make life choices and empowerment must be aimed at groups or layers of society that are left behind (Prijono \& Pranarka, 1996).

In the context of women's empowerment, Nursahbani Katjasungkana, in the Team discussion, The formulator of the National Development Strategy, stated that there are four empowerment indicators. 1) Access, in the sense of equal rights in accessing resources productively in the environment. 2) Participation, namely participation in utilizing assets or limited resources. 3) Control, namely that men and women have the same opportunity to exercise control over the utilization of those resources. 4) Benefits, namely that men and women must be equal, enjoy the results of using resources or development together and equitably.

\section{Framework}

This study describes the business processes carried out by financial institutions, sharia micro-finance institutions that use Micro Waqf Banks as research targets. Waqf Bank Micro is considered to have unique characteristics as an Islamic microfinance institution in Indonesia. It carries out its role as a financial institution and carries out community empowerment activities in business assistance, especially for women.

Research conducted in several locations will also explain the characteristics of management of financial institutions that differ from one another. Despite having the same standard operating procedures and each Institution is also equipped with the same knowledge, insight, and skills, implementation in the field will be different if the characteristics of the pesantren as the manager of the Micro Waqf Bank are also different.

Aimed to see the benefits obtained by the community as members who get financing, this study adopts the framework developed by Kato and Kratzer to explain the impact of Islamic microfinance institutions on the empowerment of women. The concept of empowerment relates to a person's ability to make life strategy choices where these abilities were previously culturally not possible to do. The idea is related to getting out of "powerlessness" to situations that make them more empowered and able to make strategic decisions in life (Kato \& Kratzer, 2013).

Women are assumed to be more empowered if they participate in Islamic microfinance's institutional services than those who did not participate. They have the opportunity to earn income through various productive economic activities that will ultimately increase their contribution to meeting family needs, access to and decision-making roles, and control over resource allocation owned by the family. 


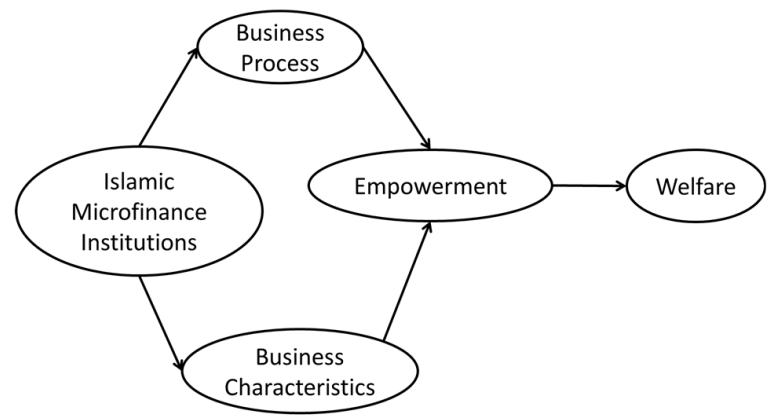

Fig 1. Research framework

\section{Research Method}

Collecting data in this study is to use the interview method, observation, and documentation. Interviews were conducted with managers and customers of the micro bank waqf in Jombang Regency. Micro waqf bank which is the object of this research includes Bank Wakaf Mikro Tebuireng Mitra Sejahtrera, Bank Wakaf Mikro Denanyar Sumber Barokah and Bank Wakaf Mikro Bahrul Ulum Barokah Sejahtera. The three are affiliated with a large pesantren in Jombang Regency. The object under study is in the form of a Micro Waqf Bank business process, business characteristics, and also the impact felt by the community around the pesantren with this institution.

Data analysis in qualitative research is inductive and continuous to result in understanding, concepts, and new theories ultimately. The qualitative approach takes a lot of time. The reliability is questionable. The procedure is not standardized, and the design is unstructured. It cannot apply to large-scale research, and ultimately research results can be contaminated with the researcher's subjectivity. The evaluation model used in this study is the Stake Model. This model provides a systematic method for evaluating community empowerment programs pesantren-based. Judging from the approach, the Stake Model is considered efficient because evaluation is directed to decision-making, and the process focuses on particular aspects of the current program. According to the system's structure, this evaluation model meets all components of inputs, methods, and results. These components according to Stake, it is called the antecedent, transaction, and outcome.

\section{Data Analysis and Discussion}

Economic empowerment is one of the efforts to increase the participation community in utilizing the economic potential that exists in the surrounding environment. Empowerment is often carried out by financial institutions that are closely related personal with society. The closest institutions that are commonly accessed by the public are in the form of Cooperatives because culturally, cooperative capital comes from members, is managed by members, and Members also feel the results.

This limited cooperative capital is one of the inhibiting factors for growth and development collaborative development. Limited access to finance makes people take shortcuts to finance with loan sharks who charge high interest in the process of solving it. This problem then became 
a separate lighter for pesantren, which have been concentrated in developing the education sector to care for the community's economic issues around the pesantren.

This study takes the object of Islamic Microfinance Institutions, the Micro Waqf Bank model, which is affiliated with primary pesantren in Jombang district, East Java. These include the Pesantren Tebuireng, the Pesantren Mamba'ul Ma'arif Denanyar and the Pesantren Bahrul Ulum Tambak Beras in Jombang. Each of these pesantren gets the mandate to manage social funds from the national Amil Zakat Institution, namely: LAZNAS BSM Ummah, to work Financial Institutions whose management is separate from the direction of the pesantren.

The emergence of Pesantren-based Microfinance Institutions in Indonesia with the model Micro Waqf Bank is one of the efforts to provide benefits and increase the community's economic potential around the pesantren. This Institution has a legal entity in the form of a cooperative established by several members. It is taken from the pesantren environment, both its caregivers and the teachers who teach at the boarding school. Even though it is a cooperative legal entity previously issued by the Ministry of Cooperatives and SMEs of the Republic of Indonesia, this Institution applied for an operational permit institution to the Financial Services Authority. The permit refers to the UU No: 1 of 2013 concerning Microfinance Institutions. The implementation of the pattern sharia as the operational basis of this Institution is included in the category of Microsharia Financial Institutions.

The selection of the Micro Waqf Bank branding in this Institution is intended to be easily recognized by the public. Although operationally, this Institution is not a bank, This Institution applies more cooperative management in carrying out activities his efforts. Based on the Law on Microfinance Institution's regulation, these institutions are limited operational areas at the district level. So, the customers served by this Institution must not come from outside the subdistrict where this Microsharia Finansial Institusin is located. It fits with the amount of existing MFI capital when applying for an operating license to the Financial Services Aauthority.

In general, the business processes carried out by Microsharia Finance Institution include:

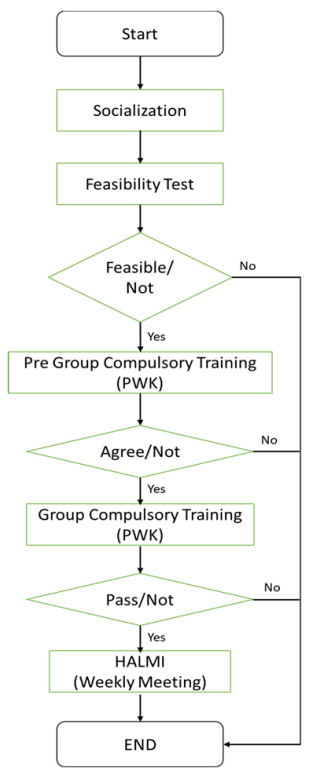

Fig 2. Business Process flow 


\section{a. Socialization to Community Leaders and Community}

The socialization of the empowerment program is carried out to community leaders at the village level and RT and RW levels. Socialization was also carried out in the study religion group and community groups based on community organizations. Because this program is carried out on a group basis, this step can be the initial foundation for building a relatively good economic empowerment group and commitment in carrying out the process of financing that the Sharia MFI has determined.

\section{b. Feasibility Test of Potential Beneficiaries of The Program}

This feasibility test is carried out with several approaches. The first approach evaluates the financing application form submitted by referring to the parameters determined by the Operational Standards procedures for this program, parameters in the feasibility test guide to the concept of analysis character-based financing, business management, business conditions, and business capital previously owned. The feasibility test is also carried out by conducting interviews with several related parties: the party providing financing recommendations, the party proposing group formation, and the potential beneficiaries of the program itself. This matter is intended so that the responsibility for financing settlement can be carried out following the proportions. In addition, several indices become test assessment parameters. Participants' eligibility includes: House Index, Income Index, Asset Index, and Index Land ownership

\section{c. Pre-Group Compulsory Training}

This process is carried out to re-assure the readiness of prospective customers recipients of financing to follow all the financing process flow starting from training mandatory group for 5 consecutive days and the mentoring process once a week during the financing process until payment. In this stage, 5 people called the Surrounding Community Business Group Pesantren Indonesia (KUMPI: Kelompok Usaha Masyarakat Sekitar pesantren Indonesia). Between 3 to 5 KUMPI ones formed can form 1 weekly Halaqoh group or called HALMI. Criteria to become a member of KUMPI, among others: included in the community category low income, have had a business for at least six months, aged between 18 to 55 years, able to take responsibility for themselves, and willing to fulfill all the rules set out in the KUMPI.

While the principle of the members in Kumpi is determined to change the way of life out from poverty, trying to improve the intention that the efforts made are not only looking for profit but also improving welfare family and worshiping God Almighty. Willing to be disciplined in everything, establish friendship and family relations with fellow members group and work hard and work smart to achieve the goals and dreams aspired.

\section{d. Group Compulsory Training (PWK)}

This activity is carried out to form and prepare groups in overall program implementation. The objectives of this activity include strengthening determination and customer interest in participating in the program to completion, forming institutions groups, introduce the mechanism for distributing revolving funds, and establish a business plan after obtaining financing. This compulsory group training is also an exercise program to provide an overview and understanding to prospective customers about the principles, objectives. It uses financing proposed, systems and procedures for implementing business empowerment programs and rights, obligations, and responsibilities of customers during the financing process. Group compulsory training held for five consecutive days with the implementation for 1 hour every 
day. It is carried out at the same time and place during its performance based on the agreement of the group members.

The first day of PWK explains the Sharia MFI Institutions and procedures implementation of the pesantren-based community business empowerment program following the principles of sharia-based financing and without collateral. In the first meeting, I explained the need to be self-disciplined in all things, including punctual attendance in follow the PWK process for five days. In this meeting, 4 (four) obligations of members were also explained. They must be present at every meeting, pay installments every week, and take advantage of financing accepted to run the business. And must carry out joint responsibility if any troubled members.

The second day of PWK explains invitations to customers to improve family welfare as the key to household harmony and advice to care for the surrounding environment. One way is to use funds financing obtained to increase the volume of business which is hereby expected can increase family income. In the pledge, it is also taught to use funds. The financing received is by the proposed and expected business plan customers can return financing funds by the specified period agreed.

In this meeting, customers are invited to get to know their group members better and ensure that their members are trustworthy, responsible, and not cheating. Each member must also understand the others about the characters. Everyone is supposed to be sincere and honest, particularly about each history that does not have debt. They must be trustworthy and do not disappear after receiving financing. They should be able to guarantee other members and sincere to raise funds if there is any who are lack in the financing. KUMPI can be disbanded if it has lost its sense of trust among members.

At this meeting, KUMPI and HALMI are introduced in the session routinely after the disbursement of customer financing. The purpose of the establishment of KUMPI and HALMI and what activities were carried out in the meeting. The purpose of establishing KUMPI is to strengthen members' determination and confidence that institutions can trust them to obtain financing without collateral. KUMPI can apply pressure on members who intentionally do not fulfill their obligations to the Institution. KUMPI is a place to lighten the burden of members if there are difficulties. KUMPI will encourage each member to comply with all rules, especially attendance weekly meetings and installment payments.

The third day of PWK explains the importance of educating and sending children to school to be smart people, decent and make the next generation a better generation. Decent children are believed to be the provision when both parents have died - the children will always pray for their parents in any condition. In addition, the pledge also explains the testimony that everything we do will hold us accountable not only in this world but also in the afterlife.

In this meeting, the technical proposals for financing have begun to be explained. Starting from the proposal, a formal application submitted at a meeting must include a funding nominal and its allocation and technical financing disbursement. Financing submitted must be used to increase business capital both for himself and for other family members.

The first financing nominal for members is IDR 1,000,000 (one million rupiahs), which can be paid in installments for 20 weeks, 40 weeks, or 50 weeks according to the ability to pay from members. The agreement or contract used by most Sharia MFI in Jombang district is a Qordh contract, a loan contract in which members return funds per received funding. Meanwhile, the income received by Sharia MFI is from mentoring activities carried out in the form of ujrah/fees/services by using a contract ju'alah. However, freed to use other sharia contracts such as murabahah, musharakah, mudharabah and ijarah.

The fourth day of PWK explains the contracts used in the Sharia MFI: the rights and obligations of members and determining the name of the member HALMI, the time and place 
of the meeting. The HALMI meeting location should not be far from the member's domicile. At this meeting, the members were deposited with IDR 100,000 (one hundred thousand) in cash and recorded by the officer with the serial number of the money and the member who brought it back at the last PWK meeting.

The last day of PWK is with the KUMPI validation exam. This exam is a related selection of whether or not KUMPI members are eligible to receive the proposed financing. This test is carried out to ensure that members have memorized the pledge and its meaning and significance real example. Members are also expected to understand and agree to the principles in providing business capital, and each member understands their responsibilities in this program.

The things tested include pledges, the background of empowerment programs, systems 221 financing, member obligations, functions and roles of KUMPI and HALMI, products sharia institutions, procedures for filing, receiving, and returning of funding and rights and member obligations. In addition, a nominal refund of Rp. 100.00 was also made to re-check the serial number is it still the same as the one received by members one day previously, to assess the level of trust of members if they are given a deposit. Graduation assessment is carried out by considering various aspects of the evaluation, including $50 \%$ mastery of material, $25 \%$ trustworthiness, and $25 \%$ discipline in PWK.

\section{e. HALMI (Weekly Meeting)}

Halmi is held every week during the financing process. This meeting becomes a means of assistance, and economic empowerment carried out by sharia MFI to its customers. During this meeting, requests for financing, approval financing, and disbursement for funding are carried out. The concept of disbursement of financing is carried out using the 221 model. In each group, KUMPI consists of 5 members; only the first two members are disbursed; funding is carried out in the first week, the following week financing is also given to 2 members, and the final disbursement is assigned to each group leader in the HALMI. Installment payments start one week after the member receives financing from Sharia MFI.

Seating positions in HALMI activities are also arranged in such a way as to make it easier for the supervisor performs attendance control and member installment control. Every meeting member seats do not change according to their respective groups and in order the recipient of the financing as stated in PWK.

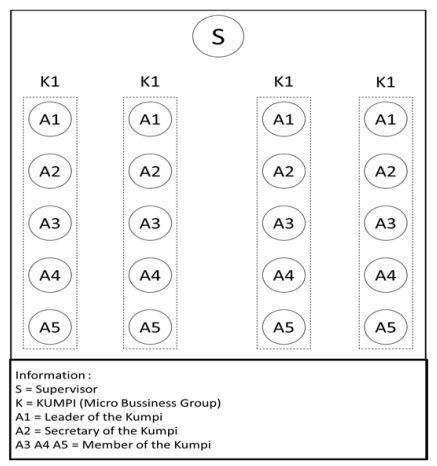

Fig 3. Member seating positions in Weekly Meeting 
The following are some of the characteristics of Micro Waqf Bank Institutions, including: a. Providing assistance and financing with sharia principles

Since the beginning, this Institution has applied for each institutional operation permits under sharia principles. Consequently, there must be supervision apart from institutional supervisors. There is also supervision from the Sharia Supervisory Board, which will ensure that all activities carried out by the Institution do not violate the principles of Sharia law set by the National Sharia Council of the Indonesian Ulema Council (DSN MUI: Dewan Syariah Nasional Majlis Ulama Indonesia). A financing product that is distributed using a Qardh (Loan) contract without interest. While the mentoring program is carried out using a Ju'alah contract (services accompaniment). Sharia MFI can recognize these mentoring services as the operating income of the Institution.

b. Only performs the function of channeling funds, does not perform the function of raising funds.

The initial fund managed by the Sharia MFI is IDR 250,000,000.-. It is used for establishing the Institution and providing the facilities and infrastructure needed by the Institution to carry out activities of its operations both for inventory and for the application of recording its financial statements. This initial fund is also used to distribute funds to 1 Halmi group that has already previously formed.

Furthermore, the donor gave this Institution the mandate to manage IDR $4,000,000,000$,- in several forms of instruments financial accounts: 1 unit of Time Deposits worth IDR 3,000,000,000,- and nine units of Deposits worth IDR 100,000,000.-. The rest is given in the form of savings and can be withdrawn by the MFI to disburse funds and their operational needs. There are many sources of funds and the risk of collection funds. Consequently, the Institution is not allowed to collect funds in the form of savings from the public. If the customer wishes to save, the savings management is submitted to KUMPI and HALMI respectively as part of the reserve fund for control of the established joint responsibility system

\section{c. Providing group financing with a joint responsibility system}

BWM has two functions that must be carried out: business institutions and learning institutions for their members and customers. As a business institution, Sharia MFI must be able to maintain and develop its assets, which will improve the quality of service to its members/customers. And as a learning institution, Islamic MFI must be able to educate their members to be independent to improve well-being. To answer the two functions of these institutions, cooperatives can apply a system of responsibility jointly because this system contains the spirit of "heavy is equal to be carried, and light is to be carried," and the point is togetherness. Joint responsibility is a system that divides responsibility equally, applying the concept of collectivity, from designing programs to overcome the problems encountered.

The advantage of this system is that everyone participates in thinking, working, and monitoring. Responsibility is divided equally so that all have the right to access information on developments in business and the results of the said business. Therefore, the joint responsibility system must become a system and value system in managing BWM Syariah MFI and must be internalized to Members, Customers, and Managers. Joint responsibilities in financial matters (savings and profit management) For example, when there is a default in installment payments from the customer to the BWM, then the one who bears it is all Halmi members where the default is a member of the KUMPI or HALMI.

The mechanism for guaranteeing default by members/customers to BWM Syariah LKM can be done in the form of a savings program or directly collected from members/customers at the time of default and at the time of HALMI implementation. Whereas mechanism for 
settlement of arrears payments between HALMI and members/customers who fail to pay is left to the decision of the respective HALMI.

\section{d. There is basic training before obtaining financing}

Every member/customer who will do the financing is required to follow basic training called PWK (Compulsory Group Training). This training is activities to form and prepare groups to take part in the implementation program. The purpose of implementing PWK is: (1) to strengthen the determination and interest in participating in the program, establishing the KUMPI institution (Business group), (2) to introduce the financing/loan mechanism that the Sharia MFI will distribute to members/customers, (3) to compile and determining business proposals for each customer, and (4) to prepare members so that they can pass the UPK (Group Validation Test) as one of the requirements for disbursement financing.

PWK is an exercise program to provide an overview and understand prospective group members regarding the principles and objectives. It uses financing/loans, systems, and procedures for implementing financing/loans, explaining rights, obligations, and responsibilities of group members/participants during the financing process. PWK is held 5 (five) consecutive days for 1 hour each day at the same place every day. The time and place of the activity are decided based on the agreement of KUMPI members. If one or more are not present when the PWK takes place, the KUMPI must repeat the PWK process from the beginning.

\section{e. Customers get assistance regularly}

The mentoring program carried out by the Shariah LKM after the participants are declared to have passed The UPK during PWK is called HALMI. HALMI is a meeting between $2-5$ KUMPI which held once a week, on the same day and time every week, for 60 minutes which consists of the initial 30 minutes for pledges and financing transactions, and 30 minutes after is the development of group members by the manager and or administrator of the Shariah MFI. HALMI activities are carried out at the house of one of the members of KUMPI in turns or above member agreement. During HALMI, there are no food, drink, and smoking. The penalty is given to the person concerned and the group for violations of time and mutual agreement. In HALMI, all members must be disciplined to maintain and maintain the integrity and safety of KUMPI and all members. HALMI is led by a chairperson and assisted by a secretary selected from the KUMPI chairman in the HALMI. The way to sit in the HALMI meeting is the same as in the PWK.

The function of the HALMI meeting is to correct the shortcomings experienced by members of KUMPI in business management, household economic management, and religion. Function others, namely improving the knowledge, skills, and attitudes of KUMPI / HALMI in managing the business, household and religious, economic management, and educate, encourage and help provide alternative solutions, if the customer is experiencing difficulties in running their business. The purpose of coaching in HALMI is to increase the awareness of group members Sharia LKM in this case, is a member of KUMPI / HALMI towards economic business behavior which is Islamic, improve the knowledge, skills of group members in management efforts, especially at the KUMPI / HALMI meeting and increasing the network of relations between Sharia MFI with KUMPI/HALMI members by helping to overcome difficulties and obstacles, both in improving the quality of their religion and their business

\section{f. Yield on financing is equivalent to $2.5 \%-3 \%$ per annum}

Because the source of funds used in this economic empowerment program comes from the designated grant funds, there is no reason for the Sharia MFI to channel financing funds to customers/members by collecting great returns. Although the contract used in financing varies, it will. However, Sharia MFIs are only allowed to burden customers with high returns equivalent 
to an interest rate of $2.5 \%-3 \%$ per year. It is intended to make micro-enterprises around pesantren more developed and empowered with a small financial burden.

Most Sharia MFI use Qordh/loans in their distribution, namely contracts loan with no additional / interest. While the income of Sharia MFIs is obtained from the mentoring program, namely using the Jualah contract, namely the promise contract or commitment to provide certain rewards for achieving the results of a job. Jualah is used for consulting products between customers and Bank Waqf Micro. In this case, the Shariah MFI of the Micro Waqf Bank acts as a consultant and customer as a client. For this consulting service, the Micro Waqf Bank Syariah LKM will get services or ujrah, the amount of which will be mutually agreed upon between the Shariah MFI and customers under predetermined value limits.

\section{g. Financing is provided without collateral}

Unlike other financial institutions that always ask for collateral in the form of collateral to financing customers, this Islamic MFI model of the Micro Waqf Bank (BWM) does not require collateral to access financing. This is because the Institution understands that one of the obstacles for the lower middle class in accessing financing is the absence of collateral that can be pledged to financial institutions. The risk in the absence of this collateral is borne by all members/customers in the one HALMI group with a joint responsibility system. Because the members already have each other in terms of group formation at the beginning, all members become guarantors for other members.

\section{h. Only serve to finance for women}

As was done by the Grameen Bank in Bangladesh by Muhammad Yunus, a member of women who follow the mentoring process and recipients of financing, if there are men who want the same program, it is recommended to include the mother, wife, or child to access this program. Become a business entity that emphasizes that the business that is run is owned together in one family, especially husband and wife so that one of the goals of this empowerment is to increase the business capacity of only members and their families. The financing program which is accompanied by this assistance has actually been tried in various places.

However, what has a high success rate is if accessing members are women. Men are more likely to find it difficult to be invited to regular weekly meetings. This is what makes this program more appropriate to say as a program for empowering women in groups with a system of joint responsibility.

\section{Outcome}

Based on the program progress report, empowering SMEs around pesantren has entered the third stage. It means that the surrounding pesantren community can feel continuity and the benefits of the program. At the initial financing stage, the funds received by members/customers are one million rupiahs. The nominal financing increases for further financing up to the maximum limit of three million rupiahs. The amount of the financing ceiling is given based on need members and also based on input and approval from other group members.

Customers feel that the mentoring program carried out by Sharia MFI brings a positive impact on economic development. The friendship between members is also getting better awake with this program. Apart from being a means to help each other, members through joint responsibility, this mentoring program also increases morale to support each other's business by buying each other's merchandise. The sustainability of the program is maintained by the existence of togetherness among members and not mutually burden. Robi (2019), in his research, said that the empowerment carried out by BWM impacts two things, namely social and economic. 
In research conducted by Safitri (2019), a program carried out by BWM effectively reduces poverty by increasing family income. While Faisal (2021), in his research on Bank Micro Waqf, stated that this empowerment program was able to improve the welfare of the community around the pesantren. Everything is in line with research conducted by Ali Hamdan (2019) that access to finance is easy and cheap for the small community produces a good impact on society related to poverty alleviation and welfare improvement.

\section{Conclusion, Implication, Suggestion, and Limitation}

The establishment of a Micro Waqf Bank in Indonesia is a unique phenomenon in Microfinance institutions, especially those whose management is based on Sharia principles. As the name implies, this Institution manages social funds intended for distribution to the community in economic empowerment. Empowerment is done to assist the community in continually building an honest, trustworthy attitude and optimism in running their business. Besides that, the assistance provided is also aimed to provide direction and guidance to the community in carrying out business by providing business management briefing to customers.

The system of joint responsibility applied in group formation is also intended to minimize the risk of default by customers. This system is used because the Micro Waqf Bank does not require collateral to customers who are prospective recipients of financing funds in the distribution of funds. The community benefits from economic empowerment activities. It is proven that customers are very enthusiastic about following the entire process even though it is tiring and requires a relatively long time. Under these conditions, hopefully, many more new micro waqf banks are sourced from donors to raise the economic level of Indonesian society as a whole.

Further research can be emphasized to analyze the financial management aspects of financial management from the Micro Waqf Bank institutional model to provide a direction for better development.

\section{References}

[1] Ahmad Jaedun. (2010). Metode Penelitian Evaluasi Program. Universitas Negeri Yogyakarta.

[2] Ali H, Listya C. (2019). Pemberdayaan Masyarakat Melalui Bank Wakaf Mikro di Jawa Timur. Annual Conference on Islamic Economic and Law. Bangkalan

[3] Ayub, Muhammad. (2007). Understanding Islamic Finance: A-Z Keuangan Syariah. Gramedia. Jakarta

[4] Azizy, Qadri Abdillah. (2004). Membangun Fondasi Ekonomi Umat (Meneropong Prospek Berkembangnya Ekonomi Islam). Pustaka Pelajar Yogyakarta.

[5] Bhatt, N and Tang, S. (2001). Making Microcredit Work in the United States: Social, Financial, and Administrative Dimensions. Economic Development Quarterly; 15; 229

[6] Dhofier, Zamakhsyari. (1985). Tradisi Pesantren: Studi tentang Pandangan Hidup Kyai. LP3ES Jakarta

[7] Faisal Bagus A A, Peni H. (2021). Peran Bank Wakaf Mikro Dalam Meningkatkan Kesejahteraan Masyarakat (Studi Kasus BWM Tebuireng Mitra Sejahtera). Journal of Islamic Economic Studies. Vol 2 No. 1, 41-55

[8] Farida Yusuf Tayibnapis. (2000). Evaluasi Program. PT Rineka Cipta Jakarta.

[9] Kabeer, N. (2001). Conflicts over Credit: Re-Evaluating the Empowerment Potential of Loans to Women in Rural Bangladesh. "World Development," 29 (1), 63-84. 
[10] Kato \& Kratzer. (2013). "Empowering Women through Microfinance: Evidence from Tanzania." ACRN Journal of Entrepreneurship Perspectives, Vol. 2, Issue 1, p. 31-59, Feb. 2013 ISSN 22249729

[11] Lexy J. Moleong. (2002). Metodologi Penetian Kualitatif. Remaja Rosdakarya Bandung.

[12] Mahmud, S. (2003). Actually, How Empowering is Microcredit? Development and Change, 34(4), 577-605.

[13] Malhotra, Anju dan Schuler .(2002). Measuring Women's Empowerment as a Variable in International Development, Background Paper Prepared for the World Bank Workshop on Poverty and Gender: New Perspectives.

[14] Marzuki. (1983). Metodologi Research. Fakultas Ekonomi Yogyakarta

[15] Mastuhu. (1994). Dinamika Sistem Pendidikan Pesantren. Indonesian-Netherland Cooperation in Islamic Studies Jakarta.

[16] Moh. Nazir. (1999). Metode Penelitian, Ghalia Indonesia Jakarta.

[17] Patton, M.Q. (1990). Qualitative Evaluation and Research Methods, Sage Newbury Park.

[18] Pitt, M. M., \& Khandker, S. R. (1998). The Impact of Group-Based Credit Programs on Poor Households in Bangladesh: Does the Gender of Participants Matter? Journal of Political Economy, 106(5), 958.

[19] Prijono \& Pranarka. (1996). Pemberdayaan: Konsep, Strategi dan Implementasi, CSIS, Jakarta

[20] Riduwan. (2007). Metode dan Teknik Menyusun Tesis. Alfabeta Bandung.

[21] Robi P. (2019). Model Pemberdayaan Wakaf Produktif pada Usaha Mikro. UIN Maulana Malik Ibrahim. Malang

[22] Rukminto, Isbandi Ali, (2008), Intervensi Komunitas: Pengembangan Masyarakat sebagai Upaya Pemberdayaan Masyarakat, Rajawali Press, Jakarta.

[23] Safitri, et al, (2019), Efektifitas Bank Wakaf Mikro Dalam Mengurangi Kemiskinan (Studi Kasus LKMS Denanyar Sumber Barokah), Jurnal Ekonomi Syariah Teori dan Terapan Vol. 6: 1936-1952

[24] Sarwono Jonathan. (1995). Penuntun Penelitian Praktis. Universitas Kristen Maranatha Bandung.

[25] Srimulyani, Eka. (2007). "Muslim Women and Education in Indonesia: The Pondok Pesantren Experience." Asia Pacific Journal of Education. Vol. 27, No.1 March 2007, pp. 85-99.

[26] Suharsimi Arikunto. (2002). Prosedur Penelitian Suatu Pendekatan Praktek, Rinika Cipta Yogyakarta.

[27] Sutrisno Hadi. (1987). Metodologi Research. Andi Ofset. Yogyakarta.

[28] Wahid, Abdurahman. (1988). "Pesantren sebagai Subkultur." Artikel dalam Rahardjo (ed), Pesantren dan Pembaharuan. Jakarta: LP3ES.

[29] Yasmadi. (2005). Modernisasi Pesantren: Kritik Nurkholis Majid Terhadap Pendidikan Islam Tradisional. Jakarta: Quantum Press. 